\title{
MUSIC IN SLOVAKIA IN THE SOCIALIST ERA - THE TOPIC FOR EDUCATION OF CONTEMPORARY YOUTH
}

\section{Strenacikova Maria}

\section{INTRODUCTION}

The socialist era is very distant for today's youth. It is common to talk about the period of Baroque, Classicism, Romanticism, Ancient times, Middle Ages, modern times, World War I and World War II, fascism, national revival... In the media, only little attention is paid to socialism, and if, mostly in connection with unfortunate events (Chernobyl nuclear power plant explosion, persecution of priests, etc.). However, this period had not only negative consequences for music development. Since music as the art is subject to what is happening in the society, for its understanding, it is necessary to know the background of its existence. It is important that young people become acquainted with the music culture in the socialist era that is very distant from them in a broader context. The following text describes music culture in Slovakia in the period of socialism in the wider context of those times.

\section{Political situation in Slovakia after the World War II and music culture}

After 1945, Slovak music underwent a complicated, very dynamic development. It responded not only to social, political and cultural changes in Slovakia, but also to many impulses coming from beyond the borders of our republic, and it was also affected by the music in Western Europe.

Historically, music development was influenced by the most important milestones, which are considered to be the years 1945 (the end of World War II and the establishment of Czechoslovakia), 1948 
(introduction of socialist establishment in Czechoslovakia), 1956 (period of criticism of the Stalin's socialist model), 196869 (occupation of Czechoslovakia and so-called normalization), 1989 (fall of socialism and establishment of democracy) and 1993 (establishment of the independent Slovak Republic). In the following text, we will focus on the socialist era.

After the end of the war (1945), the Czechoslovak Republic (Czechoslovakia) was restored. Since 1948, the Communist Party has gained power in the country, and took care of making changes in the society in accordance with Soviet policy. The establishment has changed to people's-democratic, and it brought the need for nationalization / socialization. Collectivization, gradual liquidation of private property and small-scale production, started.

\subsection{Music culture in Slovakia after World War II}

The music development after 1945 was strongly marked by the end of World War II. After certain restoration of the balance in the society, the desire for freedom, joy and the search for new directions of development came to the forefront.

Two basic lines were crystallized in music:

1. The first - favored continuity, developing already achieved results from the previous epochs. Inspiration were drawn from home (national) environment.

2. The second - preferred to seek and apply new compositional techniques, new sound qualities, tectonic techniques, etc. It has manifested itself in anti-romantic ideas, in opening up to European development and in seeking inspiration outside Slovak folk music.

\section{Socialist Realism (late 1940s - 1950s)}

As a result of the commencement of socialist political orientation, Slovak music began to develop in a specific direction. In 1948, the composers' congress accepted the Prague Manifesto, which brought 
new socialist innovation ideas. These ideas were transformed to the norms of so-called socialist realism. Theorists formulated them into practical proposals, which actually designate the characteristic features of the works of socialist realism (sometimes also called socrealism):

1. vocal and program compositions, especially cantatas, are at the forefront;

2. contemporary themes that support the state establishment are processed;

3. in the work, continuity of national tradition without the "return to the stylistics of the 19th century" dominates;

4. the works emphasize optimism and positive moods;

5. tonality, melodicism, folksiness and a simpler facture are applied to make the works more accessible to listeners.

The main features of the socialist realism art works were socialist content and national form. In spite of certain features that these works carried (style reduction, conforming to norms and standards), it is difficult to mark a composition as socrealism piece, because it has no specific features from the musical aspect. The main criterion could be the content that was reflected in the text, in the title or in dedication.

Music in Slovakia had "national form and socialist content". Composers had to conform to the imposed ideology, because if they became "dangerous", "unreliable" or "unwanted", their works could not be performed publicly and they lost their jobs. Among them were Alexander Moyzes and Ján Cikker, who were dismissed in 1948 from work at the Slovak National Theater and the Slovak Radio Broadcast. Both, however, like many others, adapted their work to new conditions and therefore, they could compose more. New conditions included e.g. strong nationalization, ideological focus on national music, selection of simplified means of expression, application of socialist themes and so on. 
Approximately from the mid-1950s onwards, composers began to reject conventions and sought new forms of individual expression. The vocal-instrumental cantatas have fallen behind and the interest was given to more chamber works. Means of expression in compositions were expanded, bearing the individual testimonies of the authors. Continuously, the building on melodic-rhythmic musical thoughts, work with motifs and modes, and polymodal structure were preserved. The orchestra's instrumentation also did not change and it emphasized the richness of sound.

\subsection{Establishment of music institutions}

During this period, the establishment of new music institutions, organizations and the strong promotion of music among folks had very positive impact on music culture.

\subsubsection{Music education}

Music schools at the lowest level and conservatories were nationalized and new music schools were included in the school system:

- 1941 - Štátne konzervatórium State Conservatory in Bratislava (nationalization of the Academy of Music and Drama in 1941),

- 1945 - Seminár pre hudobnú vedu [Seminar for Musicology] at the Philosophical Faculty of Comenius University in Bratislava (it was renewed and led by Konštantín Hudec, the author of the first history publication about Slovak music - Development of Music Culture in Slovakia),

- 1949 - Vysoká škola múzických umení [Academy of Performing Arts] (as the third stage of preparation for professional artists; Ján Strelec was the head of the school since its founding; E. Suchon̆, F. Kafenda and V. Talich were the heads of the Faculty of Music Faculty). 


\subsubsection{Performing ensembles}

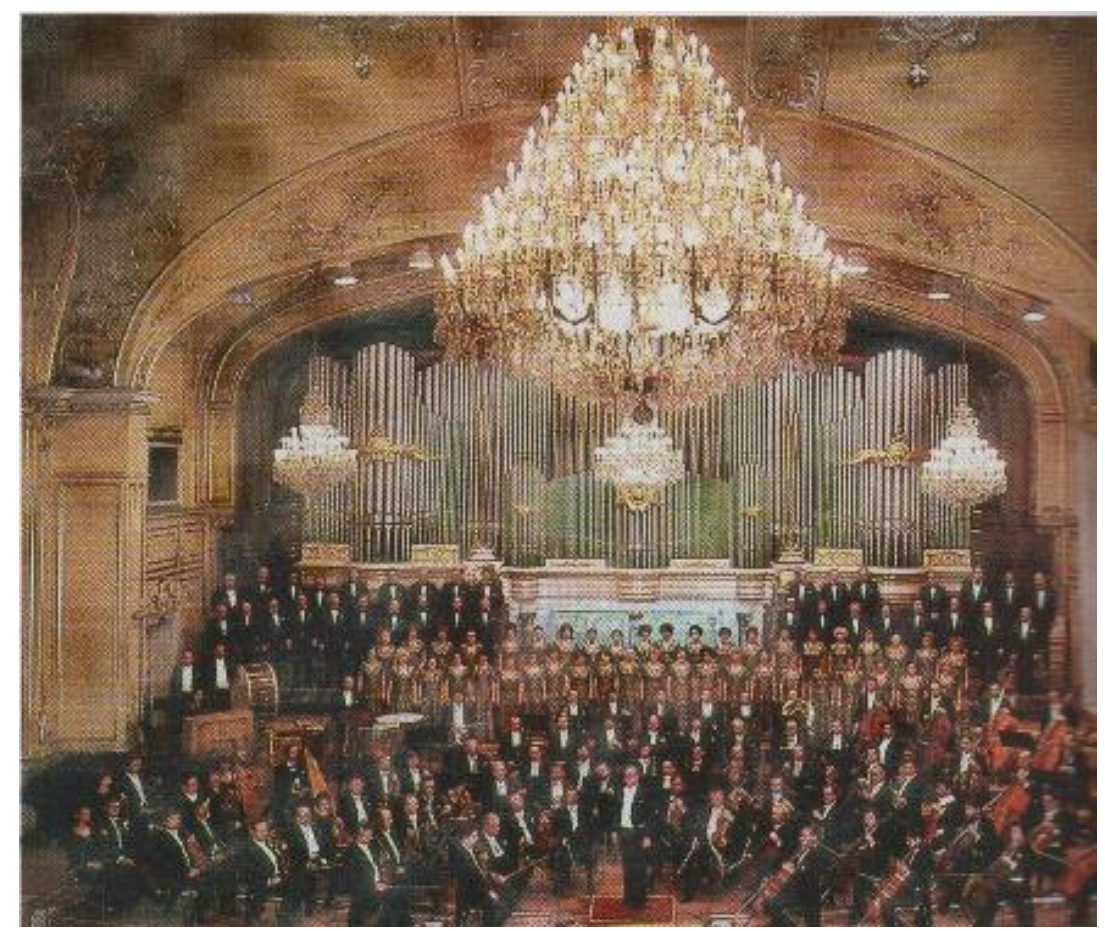

Fig. 1. Reduta in Bratislava, the home of Slovak Philharmonic

Source: Kol., 2006, p. 782

New performing ensembles appeared, many of which still exist today. They elevated the music culture and contributed to the development of musical life not only in Bratislava, but also in other Slovak towns (and villages).

- Operas: The Opera Slovenského národného divadla [Opera of the Slovak National Theater] and the Opera in Košice were nationalized; Spevohra Nová scéna [singspiel New Stage] was created (1946).

- Rozhlasový orchester [Radio Orchestra] with conductors: František Babušek, L’udovít Rajter, Ladislav Slovák, Bystrík Režucha.

- Slovenská filharmónia [Slovak Philharmonic] in Bratislava (1949) - in 1950 it became the initiator of the Bratislava Music Festival (BHS). In addition, it made many tours abroad (conductors Václav Talich, Ludovít Rajter). Since 1950, the Slovak Philharmonic has been located in the Reduta building. Until today, the Philharmonic is one of the key ensembles of Slovak music. The Slovak 
Philharmonic includes the Slovak Philharmonic Orchestra (since 1949) and the Slovak Philharmonic Choir (since 1957; originally the Mixed Choir of Bratislava Radio founded in 1946) with conductors Ladislav Slovák and since 1955 Jan Maria Dobrodinský).

- Operná scéna Divadla J. G. Tajovského [Opera scene of the Theater of J. G. Tajovský] in Banská Bystrica (1959) - the repertoire focused mainly on the romantic operas. Conductors during socialist era were: Ján Kende, René Kubinský, Josef Staněk, Ján Valach, Ladislav Matějka, Anton Buranovský, Vojtech Javora, Miroslav Šmíd, Boris Velat a Jan Šrubař, Jaroslav Krátký, and Petr Chromčák.

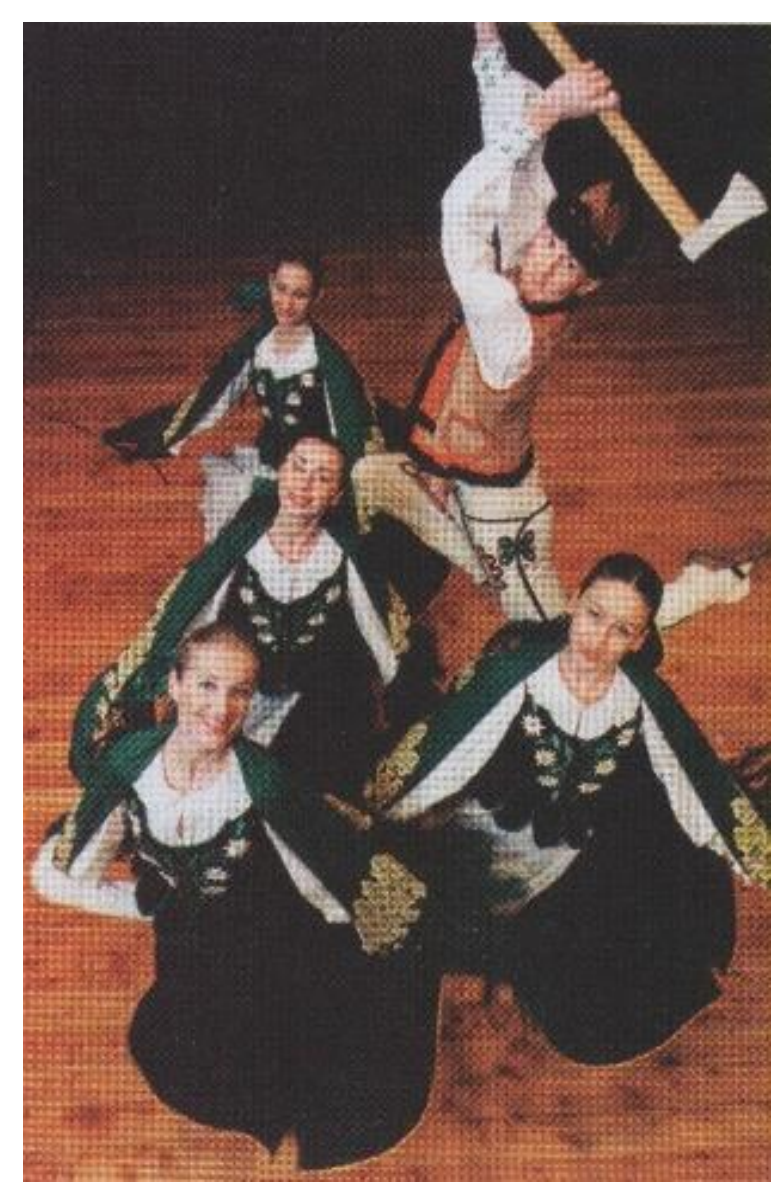

Fig. 2. SLUK

Source: Kol., 2006, p. 797

- SL'UK - Slovenský l'udový umelecký kolektiv [Slovak State Traditional Dance Company] (1949) - professional ensemble representing traditional Slovak dance, music, musical instruments, and 
costumes. Originally it consisted of two parts - the dance and the choir; since 2000 it has two components: folk orchestra and dance. At the beginning, the majority of SLUK's repertoire focused on folk culture - dance, songs and customs. Many important figures of Slovak musical culture worked with this ensemble: composers (A. Moyzes, J. Cikker, D. Kardoš, T. Andrašovan, B. Urbanec, I. Zeljenka, T. Salva, J. Malovec, I. Bázlik, S. Stračina), choreographers (Š. Tóth, Š. Nosál', M. Ťapák, J. Kubánek, J. Durovčík, E. Varga), conductors (M. Novák, choirmaster V. Adamec).

- Lúčnica (1948 - folklore ensemble of university students in Bratislava, since 1950 Lúčnica). Since 1967 Lúčnica includes the choir, dance ensemble and orchestra Golden Violin. The repertoire consists of scenic paintings inspired by folk art. More than 2000 dancers, singers and performers worked in the ensemble. Artistic director was Štefan Nosál' and the choir was led by Š. Klima).

-VUS - Vojenský umelecký súbor kapitána Jána Nálepku [Military Art Ensemble of the Captain Ján Nálepka] (1951), later Vojenský umelecký súbor [Military Art Ensemble], and since 1995 Armádny umelecký súbor [Army Art Ensemble] - professional ensemble with dance group led by P. Braun. It stopped existing in 2005.

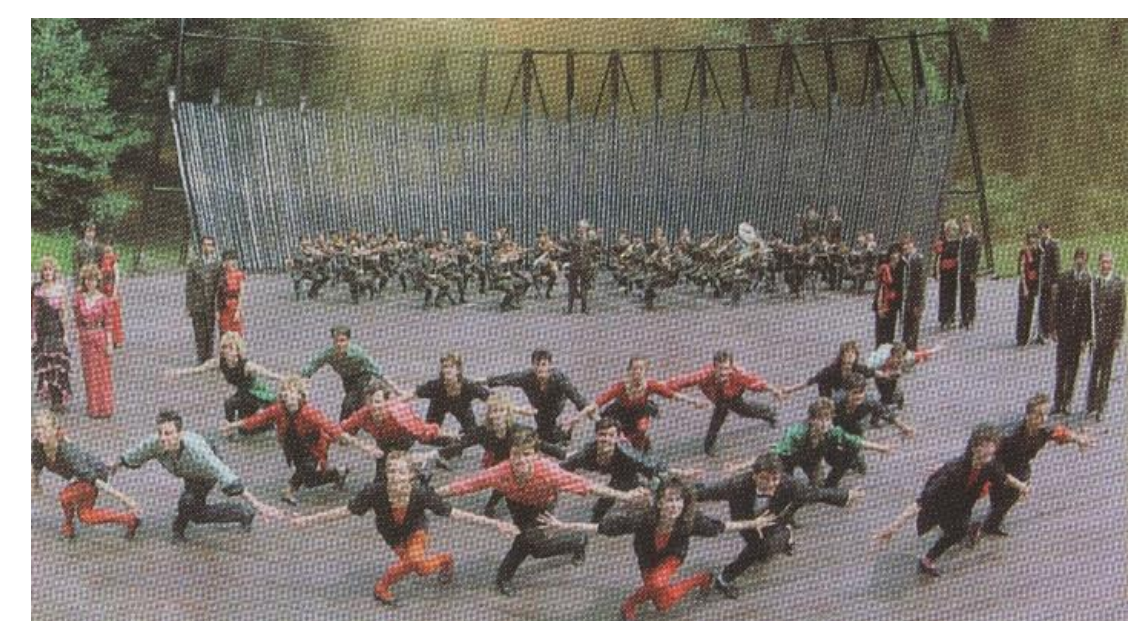

Fig. 3. Ballet performance Lysistratiáda Military Art Ensemble

Source: Kol., 2006, p. 25 


\subsubsection{Music organizations}

Music organizations played an important role in the music scene. Among them were:

- Státne hudobné vydavatel'stvo [State Music Publishing House] (1951)

- Ústav hudobnej vedy Slovenskej akadémie vied [Institute of Musicology of the Slovak Academy of Sciences] (1951)

- Zväz / Klub slovenských skladatel'ov [Union / Club of Slovak Composers] (first tour was organized in 1959, secretary Andrej Očenáš).

Slovak music culture took another significant step forward when music magazines began to be published: Hudebni rozhledy [Music Views] (1948), the monthly Slovenská hudba [Slovak Music] (1957) and the periodical proceedings Hudobnovedné štúdie [Musicological studies] (1956).

\subsection{Composers}

At the end of the 1940s, the young composers' generation was profiled in Slovakia. The most important figures, who started to compose during this period were Oto Ferenczy, Ján Zimmer, and a little later Zdenko Mikula, Tibor Andrašovan, Bartolomej Urbanec, and Milan Novák.

\section{Liberalization of art, New music, electroacoustic music (1960s)}

In 1960, the Czechoslovak Republic adopted a new name, the Czechoslovak Socialist Republic. Already the name points to its political direction. The main organ in the new socialist state was the Communist Party of Czechoslovakia. The focus on communism included the liquidation of private property, the upbringing of children and youth in the new spirit of the Marxist-Leninist ideology, and the transfer of former powers to central authorities. The new orientation led to the crisis in 1968 (Prague Spring), which the state overcame with the help of the Warsaw Pact troops. 


\subsection{New music}

Totalitarian constraints persisted in the 1960s, but the younger generation gradually formed "friendships" of composers with artists who longed for freedom. Composers began to compose works less influenced by the totalitarian regime and liberalization of art occurred. To this situation, criticism of Stalin's violence and the overall "refinement" of the dictatorship also contributed.

The new composers' generation wanted to build on the European musical avant-garde and began to seek inspiration in the so-called New music, in which dodecaphony, punctualism, serialism, aleatory and happening, as well as electroacoustic and concrete music incorporated. New compositions have temporarily appeared at concerts and mass media, although they have often been criticized (not only by political power, but also by traditional musicians). The cradle of New music was Paris, Darmstadt, Donaueschingen and other Western European cities in the late 1940s and early 1950s. New music was based on the tradition of the Second Vienna School. Newer wave of New music was represented by works by composers such as Pierre Boulez, Karlheinz Stockhausen, Luigi Nono, John Cage, Roman Haubenstock...

New composition and trends were promoted at festivals. The first Slovak work to be performed in the festival Warsaw Autumn in 1961 was Rozhovory pre flautu a fagot [Interviews for Flute and Bassoon] by V. Kupkovič. In 1967, the festival introduced work Vitazstvo [Victory] (P. Šimai), Osvienčim [Auschwitz] (I. Zeljenka) and Monumento per 6000000 (P. Kolman), under L. Rajter's wand.

In Western Europe, seminars for contemporary music were organized in Darmstadt and the New Music Festival in Donaueschingen, but our composers could not access them for political reasons.

The important musicologist promoting the need for new work was Peter Faltin (1929-1981). He initiated the establishment of the association and performing ensemble for New music, Hudba dneška 
[Music of Today], which studied the works of young Slovak composers and composers creating New Music. In August 1968, the space for P. Faltin was closed and he was forced to emigrate abroad (West Germany in 1969), where he became a recognized educator. His most important works include the book publications $\mathrm{Hudba}$ a chápanie [Music and Understanding], Fenomenológia hudobnej formy [Phenomenology of the Musical Form] and Význam estetických znakov [Meaning of Aesthetic Signs], Hudba a reč [Music and Speech]. Faltin also participated in the formation of Smolenice Seminars for Contemporary Music, which was also attended by world composers Karlheinz Stockhausen and György Ligeti.

\subsection{Electroacoustic music}

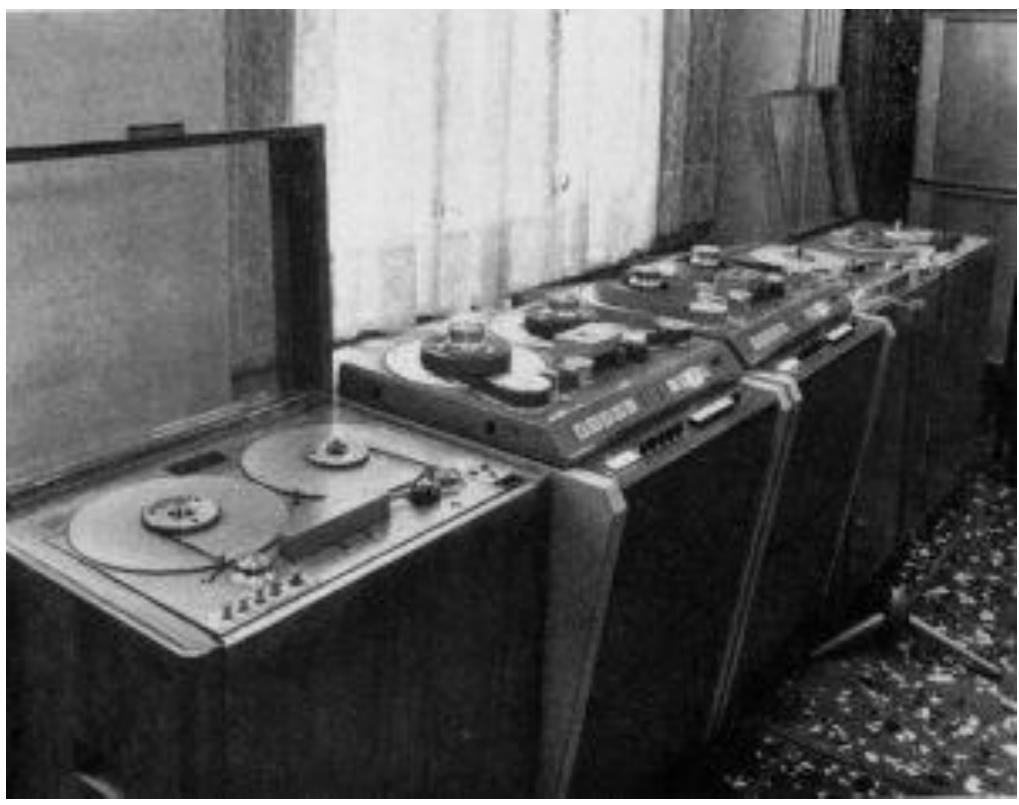

Fig. 4. Experimental Studio in Bratislava, 1965

Source: URL: http://www.sonicart.sk/archives/159

Another milestone in the development of Slovak music was the opening of the Zvukové pracovisko Československej televizie [Sound Workstation of Czechoslovak Television] (1961) and the Experimental Studio of Czechoslovak Radio (1965). Both of them opened the door to electroacoustic music. The technique that allowed to expand the sound palette fascinated many of our composers. The 
first creators of electroacoustic music were R. Berger, I. Zeljenka, P. Šimai and P. Kolman. The first authentic Slovak electroacoustic composition is considered to be the Orthogenesis by Jozef Malovec.

Electric and electroacoustic music started appearing in the radio and television broadcasts, but initially it did not have much support. Gradually, however, the new music projections have gained many fans, and since 1968 concerts with new types of compositions started to be organized. These compositions were created by L. Kupkovič, I. Parík, M. Bázlik, T. Salva, and others. Despite the increased interest, electroacoustic music recorded stagnation for political reasons after the Warsaw troops entered Czechoslovakia.

In the 1980s, when younger composers entered the Studio (M. Burlas, V. Kubička, J. Ďuriš, A. Mihalič, P. Zagar, R. Rudolf and others), electroacoustic music began to attract attention again. The greatest turning point occurred at the turn of the 1980s and 1990s, when digital technology appeared.

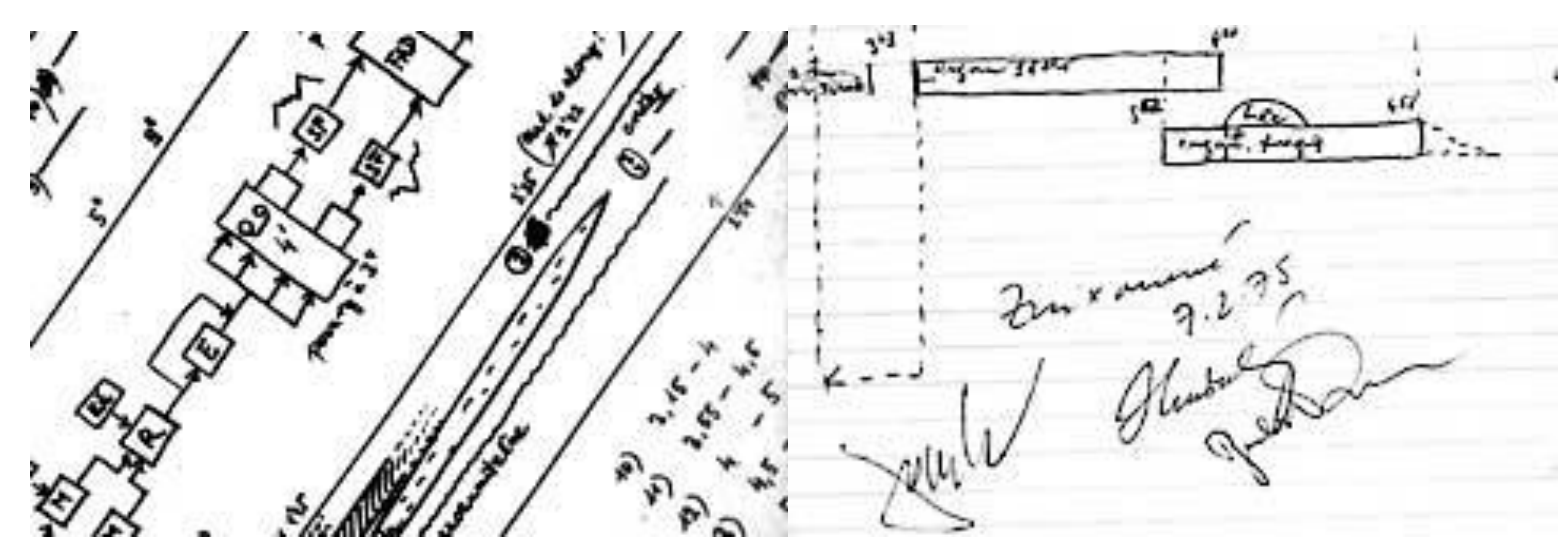

Fig. 5, 6. Fragments of patritures by P. Kolman (left) and I. Hrušovský (right)

Source: URL: http://www.radioart.sk/avr/visuopage.php?id=65

\subsection{Aleatory}

In the 1960s, Slovak composers and musicologists were meeting at various events, including the Smolenice Seminars for Contemporary Music and the Warsaw Autumn in Poland. In an effort to bring something new, modern and innovative to our music, the 
facture, form of works, time organization, notation etc. started changing.

New compositions carried certain features that point to so-called aleatory type of composition.

- Aleatory music gives to performing artist more freedom. (S)he no longer follows the exact music score, but (s)he must apply his/her own creativity and co-create the work himself/herself. The composer may designate certain quantity (small aleatory or the aleatory of the inner form) or provide only a material source for the performer (big aleatory or the aleatory of the external form).

- The music score of such music may contain not only the traditional notation, but also many graphic signs. L. Kupkovič applied big aleatory for example in the cycle Ozveny [Echoes] - Reviving 16 diapositives for chamber to large orchestra. The diapositives are projected and the performers follow composer's and conductor's instructions to complete the work. This very complex process requires great level of creativity and excellent interpretative skills. Artists can watch slides or their own scores.

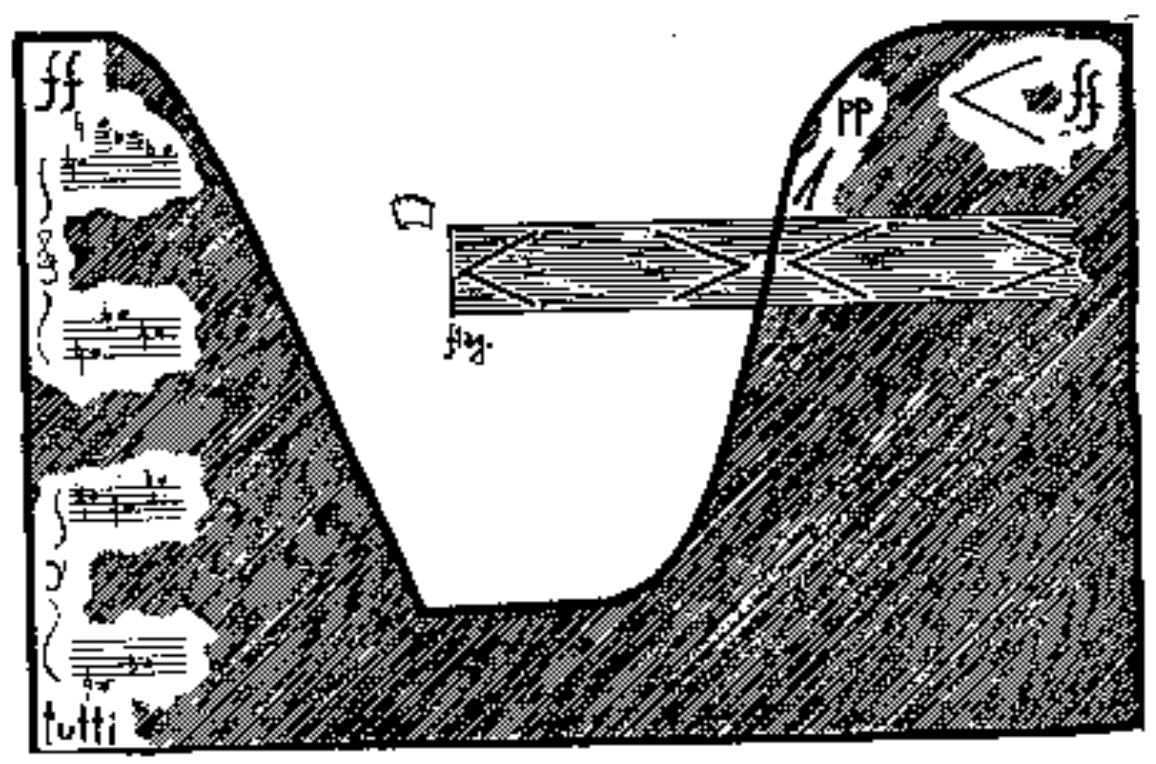

Fig. 7. L. Kupkovič: Ozveny [Echoes] (Diapositive No. 12)

Source: Radulová, 2006, p. 123, Ex. 5 
- Another feature of aleatory music is a polymetric, polyrhythmic, polylinear etc. facture.

- In aleatory music, the use of non-traditional sound possibilities of musical instruments is also characteristic. Artists searched for unconventional ways of creating tones, for example, playing right behind the bridge on string instruments, creating glissando behind the hammers in the upper half of the frame on the piano and so on.
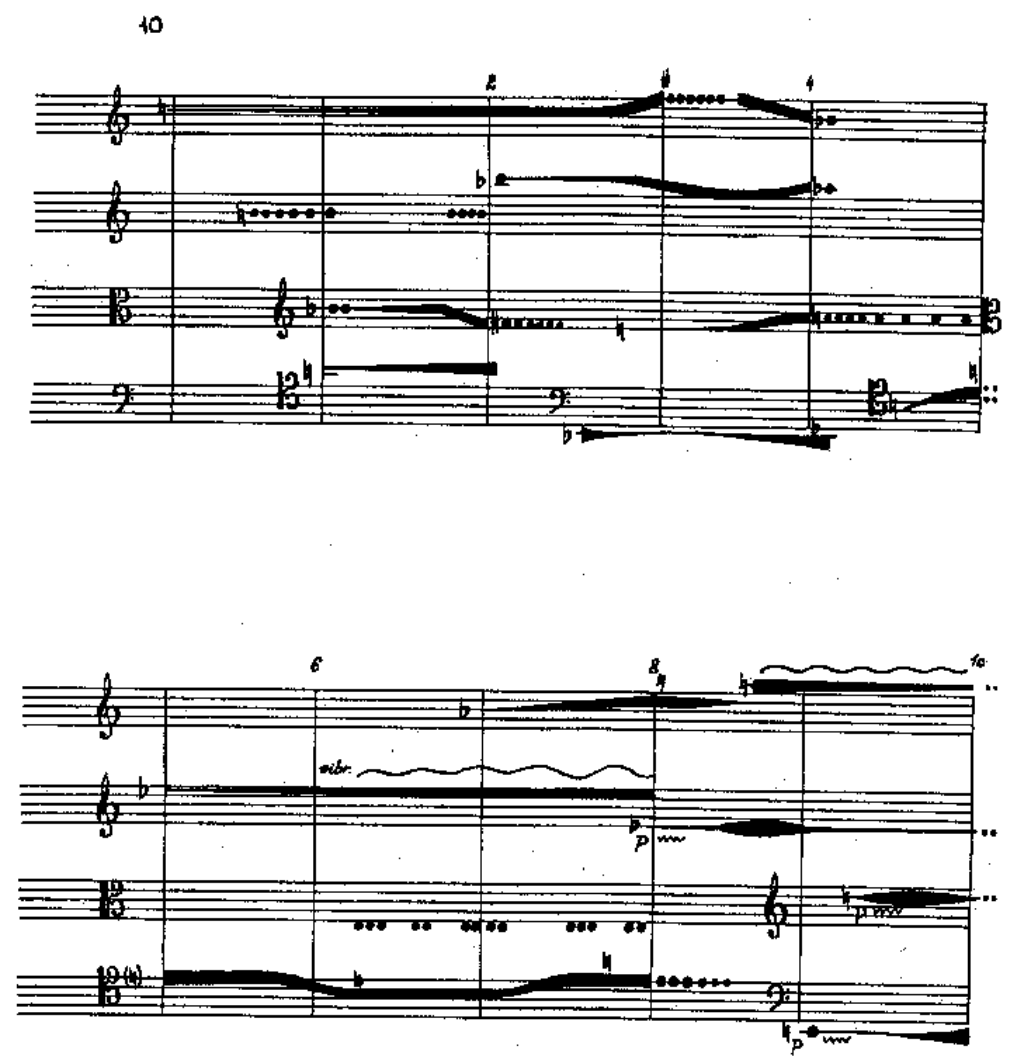

Fig. 8. I. Zeljenka: Sláčikové kvarteto č. 1 [String quartet No. 1] Source: Radulová, 2006, p. 120, Ex. 1

- Timewise, the structure of the work can be shifted from the meter measure breakdown to time periods limited by the seconds, which are the time constant (chronometric regulation). The performer actually follows certain time periods marked with signs such as 2'. An example is Sláčikové kvarteto č. 1 [String Quartet No. 1] by Ilja Zeljenka. The composer states an approximate duration of one measure of about $1.5-2$ ''. The work is composed by the technique of 
small aleatory, because in glissandos only the pitch of the first and the last tone is given, but the speed is left to the artist. Similarly, the dynamics is indicated by the size of dots size or the line thickness.

- Some composers have implement ideas of jazz improvisation into aleatory music (e.g. R. Berger).

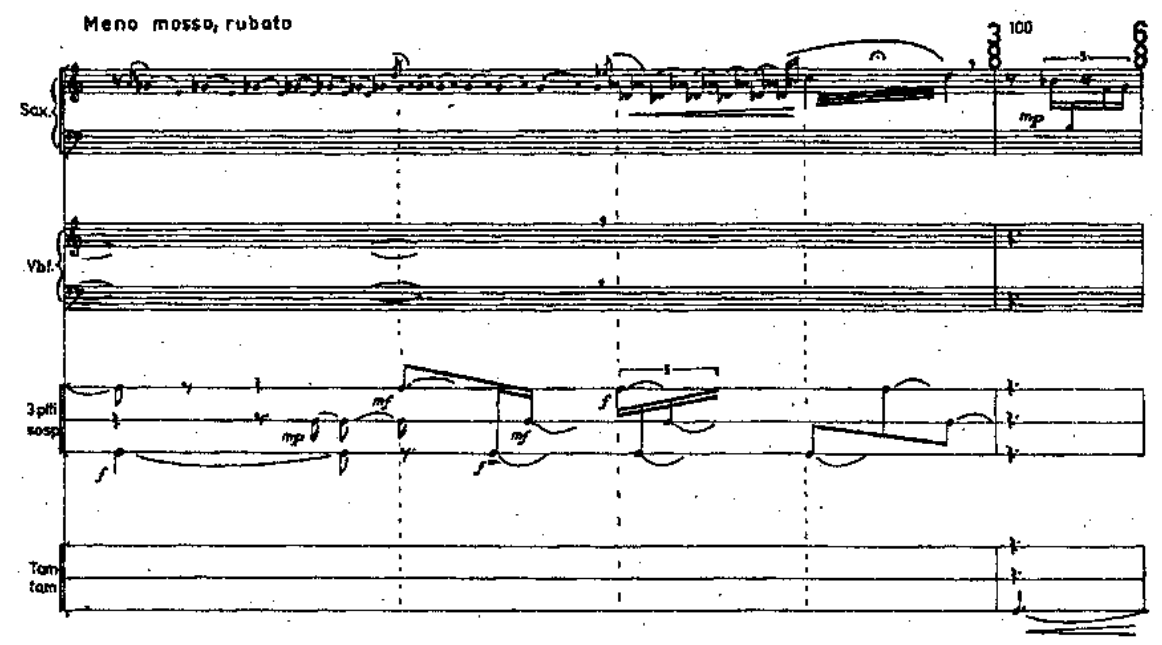

Fig. 9. R. Berger: Transformácie. Štyri skladby pre vel'ký orchester [Transformation. Four pieces for big orchestra] improvisation line of tenor saxophone

Source: Radulová, 2006, p. 124, Ex. 6

In Slovakia, the development of aleatoric compositions took place in two basic phases, which are separated in time. The first period, 1960-1965, is represented by composers Ilja Zeljenka, Ladislav Kupkovič and Peter Kolman, who drew on New music. The second time period, 1965-1970, is represented by composers Tadeáš Salva, Jozef Sixta, Ivan Hrušovský, Juraj Hatrík, and Roman Berger.

In the 1970s the development of aleatory music did not end. This kind of compositions also attracted composers in the coming period and is still composed today.

\subsection{Avant-garde movement in Slovakia}

From the above, it can be concluded, that the avant-garde movement in Slovakia took place in three phases: 
1. Latent phase (1956-1960). This phase represents the first avantgarde period. Young composers met at Seminar of Music of the $20^{\text {th }}$ Century, where they analyzed works of 20th century music (I. Stravinsky, B. Bartok, P. Hindemith...) and works of New music (P. Boulez, L. Nono, K. Stockhousen). Even in 1959 young musicians described the means of New music as "unacceptable for Slovak music". Composers: Ilja Zeljenka, Juraj Pospíšil, Ladislav Burlas, Pavol Šimai, Ivan Hrušovský.

2. Activation phase (1960-1965). Interest in New music has increased. Articles about avant-garde techniques and a new orientation of music began appearing in magazines (L. Burlas, P. Faltin), concerts and events at which the Music of Today interpreted compositions by Slovak composers were organized, many compositions were introduced at the festival Warsaw Autumn or at the events of the International Society for Contemporary Music ISCM. Experimental studio was created, which generated conditions for electroacoustic music. Composers: Miro Bázlik, Dušan Martinček, Ivan Parík, Jozef Malovec.

3. Stabilization phase (1965-1970). Avant-garde music came to the forefront and sounded at concerts, festivals, competitions and shows. Seminars of contemporary music in Smolenice were organized three times. Slovak avant-garde music also appeared on foreign stages of Warsaw Autumn (I. Zeljenka: Oswieczym, I. Hrušovský: Hiroshima, P. Šimai: Victory, later T. Salva: Canticum Zachariae). Composers: Juraj Hatrík, Tadeáš Salva, Jozef Sixta, Juraj Beneš.

\subsection{Development of musicology}

In addition to the avant-garde efforts of our composers, Slovak musicology has also developed considerably. Graduates of the Philosophical Faculty of Charles University in Prague and of the Academy of Performing Arts in Bratislava studied not only new music, its criticism, analysis and promotion, but also historical, 
psychological and aesthetic aspects. During this period, thanks to O. Elschek, ethnomusicology also began to form.

The musical history was enriched by works by J. Kresánek (Eugen Suchon̆, Melodiarium Anny Szirmay Keczerovej [Melodiarium of Anna Szirmay Keczer]), L. Mokrý and J. Tvrdoň (Dejiny slovenskej hudby [History of Slovak Music]), I. Hrušovský (Slovenská hudba $v$ profiloch a rozboroch [Slovak Music in Profiles and Analyses]), P. Faltin (Igor Stravinskij), etc. Works in the field of music theory by M. Filip (Developmental laws of classical harmony), P. Faltina (Funkcia zvuku v hudobnej struktúre [Function of the sound in the musical structure]), L. Burlas (Formy a druhy hudobného umenia [Forms and types of musical art]), and J. Kresánek (Sociálna funkcia hudby [Social function of music]).

\section{Music in the Normalization era $(1970 s-1980 s)$}

During the night of 20 to 21 August 1968, the troops of the five Warsaw Pact countries (USSR, Hungary, Poland, GDR and Bulgaria) entered Czechoslovakia, which marked the beginning of Normalization. The term "normalization" appeared in the negotiations of the Czechoslovak delegation (Alexander Dubček, O. Črník) with the USSR leaders in Moscow in August 1968. It expressed an effort to restore the Communist political line, which included i.a. the change in positions and leadership in the party and state authorities, travel restrictions when traveling to the West, closing and abolition of "enemy" institutions, stay of Soviet troops in our territory, reestablishment of centralized control over the economy etc.). The normalization era is closely associated with the accession of G. Husák to the leadership of the Communist Party of Czechoslovakia in 1969.

The returning pressure on the composers of "young" generation was again intensified after the arrival of Warsaw Pact troops to Czechoslovakia in 1968, bringing another shift to socialist realism. Composers, performers, theorists, promoters of New, modern, 
Western music have become undesirable and their works could not have been publicly performed. Moreover, the disagreements among young composers and the founding generation of Slovak music modernism culminated and ended up against young generation. Many composers were expelled from the Union of Slovak Composers, their works banned and many lost their jobs. The situation was very complicated because educated musicians had to work in areas remote from music and culture if they wanted to secure bearable living conditions. Some Slovak musicians, under the pressure of the new ideology, understood the enormous pressure and decided to emigrate to other, more friendly countries (L. Kupkovič, P. Šimai, P. Faltin, P. Kolman).

In 1970, the organization of the Seminars in Smolenice ended, the assocciation Hudba dneška [Music of Today] ceased to exist and in 1971 the magazine Slovenská hudba [Slovak Music] ceased to be published. The Institute of Musicology of the Slovak Academy of Sciences was even canceled. Ideologically directed works and politically engaged works devoted to political anniversaries (such as the Congress of the Communist Party of Czechoslovakia and the Slovak National Uprising) came to the forefront. An essential criterion for publishing and rewarding the work was its program classification. The correctness of the authors' works was supervised by the newly formed Zväz československých skladatelov [Union of Czechoslovak Composers] (1977), which directed works in the spirit of new principles and standards in accordance with cultural policy. Another feature of the totalitarian approach to music was the intervention with original works. The authors had to modify them into an acceptable form.

A very significant consequence of the political orientation was the total ban on the production of sacral music. Nevertheless, composers composed church music and used various cryptograms to hide biblical content. 


\subsection{Development of musical life}

In spite of the mentioned interventions in the music culture, which decelerated its development, the 1970s and 1980s brought the overall development of music life in Slovakia, especially performance. Many important institutions, organizations and performing ensembles have emerged and new seminars have begun to be organized.

\subsubsection{Institutions}

The development of the interpretation level in Slovakia, the numerous works of composers, and the growing interest in music have prompted the emergence of new institutions that caused further increase of musical life standards.

- Štátna filharmónia [State Philharmonic] (1969, Košice) professional symphony orchestra, participated in the organization of the Košice Music Spring and various subscription concerts. It performed the works of great masters of Baroque, Romanticism and works of Slovak authors. During the first 30 years of its existence, it has presented more than 1200 works, many of which are compositions and premieres of Slovak composers.

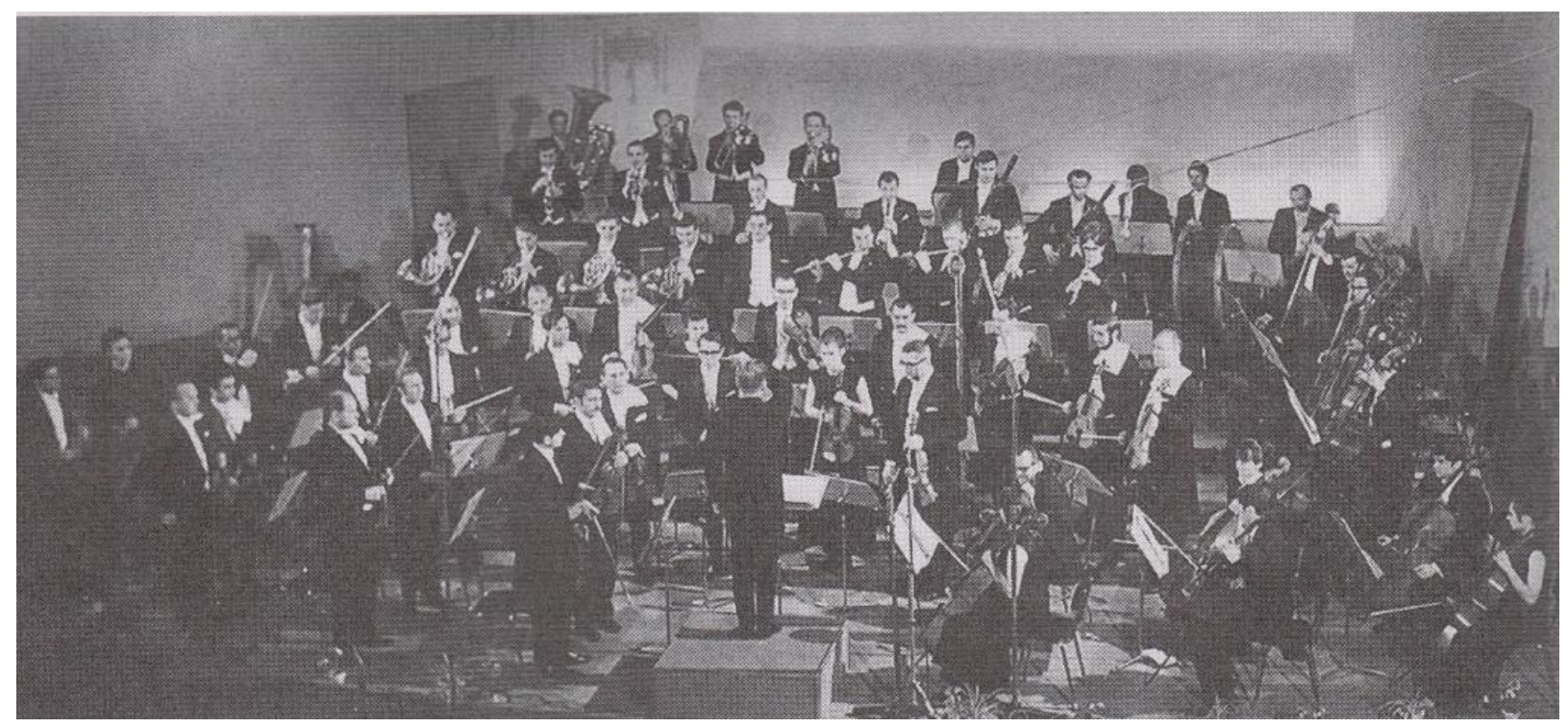

Fig. 10. Inaugural concert of the State Philharmonic in Košice 16.4.1969

Source: Urbančiková, 1999, p. 9 
- Slovkoncert (1969), an agency that organized all major music events not only in Bratislava, but also in other cities in Slovakia (e.g. Music Summer in Piešt'any and in Trenčianske Teplice). Since 1997, it worked under the Národné hudobné centrum [National Music Center] and since 1999, it has been operating as Hudobné centrum [Music Center].

- Zväz československých skladatelov [Union of Czechoslovak Composers] (1977) was created by merging the Club / Union of Slovak Composers with the Syndicate of Czech Composers.

- Hudobno-informačné stredisko - HIS [Music-Information Center] (1964); in 1973, it began organizing the International Meeting of Music Dramaturgists within the Bratislavské hudobné slávnosti [Bratislava Music Festival] and in 1985, it became a full member of the International Association of Music Libraries. Its activity at the end of the 1980s contributed to the promotion of Slovak music worldwide.

- OPUS (1971) - publishing house, which originated from the Slovak part of Supraphon. In addition to publishing gramophone records, it also focused on music literature, publishing scores, books, brochures, etc.

- Literárne a hudobné múzeum [Literary and Music Museum] in Banská Bystrica, and Múzeum klávesových nástrojov [Museum of Keyboard Instruments] in Markušovce.

\subsubsection{Chamber ensembles}

Chamber ensembles flourished in the 1970s. Those that were created earlier continued to work, and others appeared on the scene; many of them excelled in their performing quality.

- Štátny komorný orchester [State Chamber Orchestra] in Žilina (1974) - "Mozart" type orchestra. Its repertoire includes works of Baroque, Classicism, Romanticism, 20th century music and Slovak music. 
- Slovenské kvarteto [Slovak Quartet] (1957), Moyzesovo kvarteto [Moyzes Quartet] (1975), Trávničkovo kvarteto [Trávniček’s Quartet] (1973), Košické kvarteto

- Musica aeterna (1973; Ján Albrecht) and Slovenský komorný orchester [Slovak Chamber Orchestra] (1960; Bohdan Warchal).

Singing choirs formed a separate category among the ensembles. They were established in almost all major cities. In addition to adults (male, female and mixed), children's choirs began to appear. Special type of choirs were academic choirs (formed at universities).

\subsubsection{Seminars and cultural music events}

Seminars and cultural events continued to be organized. A new event called Semináre mladých hudobných vedcov [Seminars of Young Music Scientists] took place, where analyzes of Slovak composers works were presented. The tradition of Bratislava Music Festivals continued, and it included separate presentations of young artists from socialist countries - Interpódium. An important international event was Tribúna mladých interpretov UNESCO [Tribunal of Young Interpreters of UNESCO]. In 1976, a new festival Týždeň novej slovenskej hudobnej tvorby [The Week of New Slovak Music Production] featuring politically engaged works, was established.

An indisputable contribution to the development of musical life was the new magazine Hudobný život [Music Life] (1969) and the periodical Hudobný archiv [Music Archive], published by the Department of Music Manuscripts at Matica slovenská (all-nation cultural institution) in Martin.

\subsection{Composers}

During the 1970s, the composers' community was expanded by the new generation of composers (Vladimír Bokes, Hanuš Domanský, Igor Dibák, František Poul, Jozef Podprocký), and by older composers who had previously worked as pedagogues and conductors 
(Zdenko Mikula, Tibor Andrašovan, Bartolomej Urbanec, Milan Novák, Pavol Bagin, Miloš Kořínek).

In the 1980s, during the onset of postmodernism, two waves could be distinguished. The first one was formed by Vladimír Godár, Iris Szeghy, Vit'azoslav Kubička and the second one by Martin Burlas, Daniel Matej, Peter Martinček, Pavol Malovec, Alexander Mihalič, Robert Rudolf, Peter Zagara.

The composers' community of this period extended among others prominent figures, such as Julius Kowalski, Alfréd Zemanovský, Jozef Grešák, and Jozef Gahér.

\section{CONCLUSIONS}

The development of Slovak music in the socialist era is often an unknown area of music history for young generation. Despite the totalitarianism, normalization, limitation of the work of some composers and their subsequent emigration, or the prohibition of sacral music, etc., the period after the end of World War II brought indisputable positives, such as founding music institutions, conducting festivals and overall development of musical life. Many musical ensembles, which are still working today, have been established in Slovakia, and music magazines, which also still exist, have started to be published. In the period from the introduction of socialism in 1948 until its fall in 1989, the stages of intense ideological control alternated with the stages of so-called "thaw", when "liberalization" of art, which brought the spread of avant-garde streams in Slovak music, ensued. New music, aleatory and electroacoustic music appeared. At the end of the socialist period, two waves of postmodernism hit the Slovak music scene.

\section{SUMMARY}

In every country and during each historical epoch, the music culture is influenced by a number of factors that create conditions for its existence and development. Therefore, in order to understand the 
development of music culture, it is necessary to perceive it in a broader context - social, political, and economical. In the history of each country, there are periods that are more talked about and better known by inhabitants, but there are also those, about which people hear many controversies, have doubts and uncertainties. One of them is, in Slovakia, the era of socialism, especially in the eyes of the young generation. For that reason, the following text focuses on the socialist era and describes the development of music culture in Slovakia in a broader context, the knowledge of which is essential for understanding music history in today's youth.

During the period of socialism (1948-1989), music in Slovakia developed under the pressure of socialist politics. Music development can be divided into several sub-periods. The first one was socialist realism (the late 1940s and 1950s), when the works had socialist content and national form. The 1960s brought the liberalization of art and New music, aleatory and electroacoustic music began to appear more frequently on the music scene. After the entry of Warsaw Pact troops into the territory of Czechoslovakia, the period of normalization began, when the pressure to restore the communist line intensified. Although the works of the composers were censored and "guided", in Slovak music world the emergence of postmodernism occurred (in two waves). At the end of the 1980s a revolution took place, and the fall of totalitarianism made it possible to present works that normalization did not allow or recognize, and again, the opportunities for the development of spiritual music were created. However, the undisputed negatives of the socialist era were counterbalanced by its positives. Socialism strongly supported the founding of music institutions, the establishment and operation of musical ensembles (all within the boundaries of communist ideology) and the organization of many concerts and music events. 


\section{REFERENCES}

1. Bokesová, Z. et al. Dejiny slovenskej hudby. Bratislava: Slovenská akadémia vied. 1957. p. 540.

2. Čárska, E. Ivan Hrušovský: "Hudba je nekonečným vesmírom...”. In Slovenská hudba revue pre hudobnú kultúru, 2007, Vol. XXXIII, pp. 67-73.

3. Čierna, A. Poetika elektroakustických kompozícií Jozefa Malovca. In Osobnosti slovenskej hudby II - zborník príspevkov z tretieho a štvrtého Seminára Tadeáša Salvu, Lúčky pri Ružomberku 2003 a 2004. Banská Bystrica: Akadémia umení. 2006. pp. 51-63.

4. Dubovský, R. Elektroakustická hudba na Slovensku. URL: http://www.radioart.sk/avr/visuopage.php?id=22

5. Elschek, O. Hudba, umenie, politika a totalitarizmus v strednej Európe. In Slovenská hudba revue pre hudobnú kultúru, 2006, Vol. XXXII, pp. 5-15.

6. Hrčková, N. Dejiny hudby VI; Hudba 20. storočia (2). Banská Bystrica: IKAR. 2006. p. 544.

7. Hrušovský, I. Slovenská hudba $\mathrm{v}$ profiloch a rozboroch. Bratislava: Štátne hudobné vydavatel'stvo. 1964. p. 460.

8. Hudec, K. Vývin hudobnej kultúry na Slovensku. Bratislava: Slovenská Akadémia vied a umení. 1949. p. 125.

9. Husárová, Z. Experimentálne štúdio Bratislava; interview. 2013. URL http://www.sonicart.sk/archives/159.

10.Chalupka, L. Inšpirujúca symbióza teórie a praxe. K dielu Ladislava Burlasa a Ivana Hrušovského. In Hudobný život, 2007, Vol. XXXIX, No. 6, pp. 14-17.

11.Chalupka, L. Jozef Malovec, Orthogenesis. In Hudobný život, 2002, Vol. XXXIV, No. 4, pp. 29-30.

12. Chalupka, L. Niektoré paradoxy vývoja slovenskej hudobnej kultúry v 40. rokoch. In Štyridsiate roky 20. storočia v slovenskej literatúre; Zborník z vedeckej konferencie v Bratislave. Bratislava: 
Filozofická fakulta Univerzity Komenského v Bratislave. 2006. pp. 191-207.

13. Chalupka, L. Postrehy $\mathrm{k}$ individuálnemu rozmeru tvorby Jozefa Malovca. In Osobnosti slovenskej hudby II - zborník príspevkov z tretieho a štvrtého Seminára Tadeáša Salvu, Lúčky pri Ružomberku 2003 a 2004. Banská Bystrica: Akadémia umení. 2006. pp. 15-32.

14. Janek, M. Dejiny slovenskej hudby. Banská Bystrica: Pedagogická fakulta UMB. 1999. p. 76.

15. Malinowski, W. Socialistický realizmus? Čo to naozaj bolo? Príspevok k dejinám sacrum v umení. In Slovenská hudba revue pre hudobnú kultúru 1, 2006, Vol. XXXII, pp. 42-64.

16. Malovec, P. Život a tvorba Jozefa Malovca. In Osobnosti slovenskej hudby II - zborník príspevkov z tretieho a štvrtého Seminára Tadeáša Salvu, Lúčky pri Ružomberku 2003 a 2004. Banská Bystrica: Akadémia umení. 2006. pp. 9-13.

17. Martináková, Z. Základné východiská v tvorbe J. Malovca (1933-1998). In Osobnosti slovenskej hudby II - zborník príspevkov z tretieho a štvrtého Seminára Tadeáša Salvu, Lúčky pri Ružomberku 2003 a 2004. Banská Bystrica: Akadémia umení. 2006. pp. 65-74.

18. Martináková-Rendeková, Z. Ivan Hrušovský - integrálna osobnost' slovenskej a európskej hudobnej kultúry. In Slovenská hudba revue pre hudobnú kultúru 1, 2007, Vol. XXXIII, pp. 60-66.

19. Mencwel, A. et al. Socrealizmus? Redakčná diskusia. In Slovenská hudba revue pre hudobnú kultúru 1, 2006, Vol. XXXII, pp. 65-75.

20. Kolektív. Ottova encyklopédia Slovensko A-Ž. Praha: Ottovo nakladatel'stvo. 2006. p. 1056.

21. Oremusová, A. Mlčanie zo strachu; rozhovor s Ivanom Martonom o hudobnom živote na Slovensku v 2. polovici 20. storočia. In Slovenská hudba revue pre hudobnú kultúru 1, 2006, Vol. XXXII, pp. 104-116. 
22.Radioart.sk. 2010. URL: http://www.radioart.sk/avr/ visuopage.php?id $=65$

23. Radulová, S. Aleatorika ako inovačný prvok v slovenskej hudbe 60. rokov 20. storočia. In Slovenská hudba revue pre hudobnú kultúru 1, 2006, Vol. XXXII, pp. 117-128.

24. Szczepańska-Lange, E. Na Slovensku vyzerala "normalizácia" na pohl'ad vel'mi humánne; rozhovor s prof. Nad'ou Hrčkovou. In Hudobný život, 2009, Vol. XLI, No. 10, pp. 10-13.

25.Urbančíková, L. Štátna filharmónia Košice. In Hudobný život, 1999, Vol. XXXI, No. 5, pp. 9-15.

Information about the author: PaedDr. Strenacikova Maria PhD., Teacher at the Faculty of Music Arts, Academy of Arts in Banska Bystrica 22, Kollarova str., Banska Bystrica, 97401, Slovakia 